\title{
GEOGRAPHICAL PERSPECTIVES ON AGRITOURISM IN THE CZECH REPUBLIC
}

\author{
Ondřej KONEČNÝ
}

\begin{abstract}
Besides more traditional tourist enterprises, tourists in Western Europe and North America regularly seek out even more specific forms of tourist opportunities, such as products of rural tourism. Within rural tourism, agritourism has been developed in these countries as a particular subset, and its significant enhancement in post-socialist European countries was widely anticipated (especially after their integration into the European Union). While considerable and focused attention was devoted to the implementation of agritourism strategies and the characterization of agritourist space with respect to particular countries (e.g. Poland and Slovenia), in Czech geographical literature it has remained a noticeably absent topic. In this paper, central attention is paid to selected characteristics of agritourist space in the Czech Republic, analyzed on the basis of a compiled database of farms diversified into tourism at the municipality level.
\end{abstract}

\section{Shrnutí}

\section{Agroturismus v České republice: geografická perspektiva}

Turisté v západní Evropě a severní Americe pravidelně vyhledávaji mimo tradiční formy turismu specifické produkty jako agroturistiku, přičemž bylo uvažováno, že se tato forma turismu významně rozšǐrí $i v$ prostředí postsocialistických evropských států. Zatímco některým postsocialistickým státům (např. Polsko či Slovinsko) byla $v$ tomto tématu věnována cílená pozornost, uplatnění agroturistiky a charakteristika agroturistického prostoru $v$ Česku je v geografické literatuře spíše opomíjeným tématem. Článek proto věnuje stěěejní pozornost vybraným charakteristikám agroturistického prostoru v Česku analyzovaným na základě sestavené databáze farem s aktivitami $v$ cestovním ruchu na úrovni obcí.

Keywords: agritourism, agritourism space, rural areas, European Union, Czech Republic

\section{Introduction}

Socio-economic and political changes taking place in the Czech Republic in the last two decades are significantly reflected in the transformation of the Czech countryside and in the way society claims this space (Chromý et al., 2011; Svobodová et al., 2011). With numbers of farmers continually dwindling, those who remain in business are forced to cope with substantial price and demand instability with respect to agricultural commodities, international competitors and tightening economic conditions designed to protect the environment and to safeguard ethical breeding and the welfare of livestock (Bičík, Jančák, 2005; Věžník, Konečný, 2011). These current risks of farming allegedly can be reduced by diversifying the farm business to include other activities in order to eliminate and compensate for any possible loss incurred due to the predominance of agricultural production, and thus increase farm revenues (the diversification of activities - Vernimmen et al., 2003; Sharpley, Vass, 2006). Regarded as one possible remedy to the above-mentioned problems of current agricultural entrepreneurship, agritourism as an option calls for farm diversification to include recreational and leisure time activities through offerings of accommodation, catering and leisure services (Barbieri, Mahoney, 2009). This process is seen by many authors as one of the manifestations of a conceptualized post-productivist transition of agriculture/ rural areas (Ilbery, Bowler, 1998) or of multifunctional transition (Wilson, 2008).

In Western Europe and North America agritourism is already established among traditional and popular forms of leisure, education and recreation (Nilsson, 2002), but in the Czech context it is still a rather new concept. Historically, it was not until the transformation of the political system that agritourism could begin to strive for its position, as before 1989 many obstacles hindered any increased development of tourism, including agritourism (Williams, Baláž, 2002) and some of these formed barriers to development even in the following era (Clarke et al., 2001). Despite the positive dynamics of the tourism market and the opening of the country to foreign tourists in the early nineties (Vágner, 2007), no such increase in agritourism has been recorded in the Czech Republic, compared to neighbouring Poland (Duridiwka, 2003) or Slovenia (Verbole, 2000; Svobodová, 2008).

This situation is in contrast to the fact that the promotion of agritourism has long been enshrined in various strategic and conceptual documents targeted at rural development (e.g. in the Rural Development Programme 2007-2013, Ministry of Regional Development of the Czech Republic, 2007), and despite finding that its high attractiveness among other means of diversification, has been confirmed in studies from the South-Bohemian Region (Škodová, Parmová and Dvořák, 2009) or Slovakia (Buday et al., 2009). Furthermore, contrary to this widely expressed support at the strategic and planning level, the current role and dimensions of agritourism in the Czech Republic, whether from a European, regional or local perspective, have not received any considerable attention in Czech geographical research.

Therefore, the aim of this article is to explore Czech agritourist space, as it represents a basic playing field for Czech agritourism entrepreneurs who are naturally forced to 
adapt their ventures to its specifics. To identify and examine such characteristics is a necessary first step in any attempt to enter the up-to-date informed international discussion of the agritourist space phenomenon (Durydiwka, 2003; Fleischer, Thetchik, 2005; Sharpley, Vass, 2006; Choo, Jamal, 2009; Sznajder et al., 2009; Lukić, 2013). This study of the location of individual agricultural holdings providing tourists with hospitality services (lodging and accommodation in particular) at a local level, seeks to prove or disprove the assumptions that agritourism is concentrated in areas:

- Of stabilized and peripheral rural municipalities;

- That are less favoured for agriculture;

- That are typical for their natural attractiveness and ecological stability of landscape; and

- Are massively popular with tourists.

\section{Key theoretical background}

Although there are many terms and labels used to describe the notion of "agritourism", its core definitions obviously build on the linkage of tourism and agriculture, or to put it differently, on the contact of tourist and agricultural activities. According to Sharpley and Sharpley (1997, p. 9), among other authorities, "agritourism represents tourism products which are directly connected with the agrarian environment, agrarian products or agrarian stays". A review of the relevant literature reveals that many authors use other terms with the same meaning, such as farm tourism, tourism on farms, farm-based tourism or even rural tourism (Haugen, Vik, 2008; Phillip et al., 2010; Tew and Barbieri, 2012; Potočnik-Slavič, Schmitz, 2013). On the other hand, some authors reiterate the need to distinguish among these terms to avoid them being used interchangeably. For example, Fleischer and Thetchik (2005) demonstrated the difference between the meaning of the concept of agritourism and rural tourism in a number of characteristics, as for instance in the amount of time devoted by a farmer to the development of tourism, the number of accompanying attractions and the level of programming special events, scale of agritourist services offered, etc. Most commonly, agritourism and rural tourism are understood and treated as distinct concepts, with agritourism denoting a subset of rural tourism as a broader concept (Sznajder et al., 2009). In their research of providers of lodging and accommodations in the Czech countryside, Dömeová and Jindrová (2011) found that less than one third is in any way connected to agricultural production and thereby might be understood as operating as an agritourism venture. Therefore, within the typologies of agritourism (see e.g. Fleischer, Tchetchik, 2005; Phillip et al., 2010), even farms are distinguished which are no longer involved in agricultural production (non-working farms), yet they maintain their agricultural nature and participate in rural tourism activities (such as horse riding, hunting and fishing, etc.).

Moreover, farm diversification is also seen as an important element applied in (or a type of) so-called multifunctional agriculture (Marsden, Sonnino, 2008), or else it is frequently mentioned in connection with current debates on multifunctionality in agriculture. According to Wilson (2009), the degree of multifunctionality (weak to strong) at the regional level is crucial for diversification opportunities available to farmers; in another study, Wilson (2008) seeks to prove that strong multifunctionality of farms located in upland and mountain areas correlates with the nature of these localities (high nature value) allowing a greater degree of multiplier effects, such as diversification of farms through on-farm tourist enterprises. The influence of the particular location of a farm on its decision to undertake particular multiplying activities, such as nature and landscape conservation and tourism, is highlighted in another study from the Netherlands (Jongeneel et al., 2008). These highland and mountainous areas usually form part of the defined areas less favoured for agriculture (based on the Common Agriculture Policy), with farms largely dependent on agricultural subsidies (Střeleček et al., 2008; Štolbová, Hlavsa, 2010), and this factor increases the need to exploit tourist potential as a means of further development of the given area, as well as of farms located therein (Riberiro and Marques, 2002; Sharpley, Vass, 2006).

Takingtheseconsiderationsintoaccount, many researchers have tried to evaluate the tourism potential of Czech rural municipalities/areas and to create a typology based on different perspectives (Bína, 2002; Zuzák and Hořejší, 2004; Vystoupil et al., 2006; Mikulec, Antoušková, 2001). For example, Bína's (2002) natural subsystem potential consists of the components of tourism based on active tourism, recreation, and cognition of nature or of the components, which utilize nature, such as the surroundings for specialized sporting activities. Jarábková (2010) tried to identify the development potential of the tourism industry in rural areas of Slovakia, and to single out municipalities with high natural, cultural and historic potential available, together with a stable environment unaffected by industrial activities, a quality and sufficient infrastructure (regarding its capacity) fitting for long-term stays of tourists, and a quality human potential.

The area of a farm providing agritourist services, its natural landscape and the landscape of the expanse that is the result of human activity, constitute "agritourist space" (Sznajder et al., 2009). Lane (1992), quoted in Sznajder et al. (2009, p. 55) as one of the first researchers who called for the need to explore agritourist space as an essential determinant of agritourism development, distinguished six factors that determine the value of this space - among them, the value of landscape beauty and areas of wild nature and wilderness, as being the most applicable. In Sznajder et al. (2009), this idea of the need to determine particular agritourist spaces was further elaborated and, among other elements, the relevance of factors such as configuration of the area, forms of terrain, natural fauna and flora, and type of land use, was emphasized. Appealing semi-natural or natural preserved landscape implies greater dynamics in the development of new landscape functions (in addition to traditional crop and food production - Fig. 1 - see cover p. 2), including rural tourism and agritourism. Such characteristics are widely represented in the Czech border regions adjacent to Austria and the former West Germany previously shut down by the Iron Curtain (Bičík, Kabrda, 2007).

Agritourism or rural tourism is often perceived by Czech experts as a beneficial tool and a possible avenue for developing areas with the defined favourable conditions for tourism in general (but also for the development of the countryside as a whole), among other possibilities (see Jančák, 2001; Ryglová, 2007; Šimková, 2007; Svobodová et al., 2011). Spišiak (2003, p. 414) went beyond this, dealing with a less attractive Slovak territory of the Pridunajsko micro-region, when he claimed "that agritourism and rural tourism represent a new progressive orientation of the local agricultural companies." Many studies reveal that 
agritourism is indeed concentrated in areas which are already established as popular tourist destinations, as "in this case, visitors are willing to pay a higher price for a firm located in a region that is rich in tourist attractions" (Fleischer, Tchetchik, 2005), and consequently, in popular tourist areas agritourism can generate greater farm revenues (Sharpley, Vass, 2006). For example, Lukić (2013) reported that most of the households with agricultural production - tourism, accommodation and other leisure activities - are located in the littoral counties of Croatia, reflecting the importance of mass-tourism for the development of farm tourism.

It can be argued that this is why agritourism activities also develop within different kinds of natural protected areas, which accordingly play a dual role when, as well as providing a refuge for wildlife, they also serve as popular tourist destinations (Sznajder et al., 2009; Lukić, 2013). The protected environment is undoubtedly attractive to organic farms involved in tourism, as they are in general forced to operate in worse agricultural conditions: Klapka et al. (2005) illustrate that 70 per cent of organic farms operating in the Krkonoše Mts. (Giant Mountains) have taken on some form of tourist on-farm enterprise. Choo and Jamal (2009, p. 450), studying South Korean organic farming and its blending with tourism, suggested that "while the Korean organic farms are rural, they are neither remote nor "wilderness" areas; a close symbiosis and synergetic relationship with biophysical systems and the land makes them a hybrid mixture of the 'cultivated' and 'natural'."

Despite the undeniable importance of the nature of a locality and of the agritourist space, in which any farm operates and which is, at the same time, co-determined by this farm, this crucial geographical/spatial determinant of the development of agritourism has been explored only to a very limited extent in the relevant literature, and studies focused on these issues remain sporadic (see, for instance, Klapka et al., 2005; Cigale et al., 2013; Lukić, 2013). Marketing and management, motivation for the involvement of farmers in this type of business, and their attitudes monitored at a national level, have received much more attention and consideration at this time (Nilsson, 2002; Sharpley, Vass, 2006; Haugen, Vik, 2008; Dömeova, Jindrova, 2011; Forbord et al., 2012).

\section{Data and methodology}

Given the absence of data collected at the Czech local (municipality) level, selected characteristics of agritourist space in the Czech Republic were studied on the basis of a set of farm entities identified through a survey of web databases. These Internet databases could be utilized as a helpful tool for obtaining missing information (Choo and Jamal, 2009), since it is through these databases that farms often promote and offer their services for tourists (on-farm accommodation and lodging in particular). The results and findings of the research team from the Czech University of Life Sciences (Dömeová, Jindrová, 2011) and the conclusions of expert discussions (Ryglová, 2007), indicate that this method of promotion is the principal form of product communication for most providers of agritourist services and offerings of rural tourism in the Czech Republic. It can therefore be assumed that the entities participating in the agritourism industry are actively using this form of advertising.

In the first place, the databases were scrutinized in order to select those focusing on farms offering services in agritourism and rural tourism, and subsequently, the scope and employability of the selected databases had to be assessed in detail. Eventually, the following databases were singled out (as of the summer of 2012):

- ubytovaninafarme.cz (administrator: Farmy.cz, s.r.o.);

- tourist portal of the Czech Republic (czecot.cz);

- portal of Association of Private Farming (ubytovani-nafarme.cz); and

- portals of Rural Tourism Union (prazdninynavenkove. cz, is.svazvt.cz).

Farm entities identified via these databases were subsequently complemented and compared with records on agritourism providers managed by individual regions. Examination of other databases proved ineffective as no entities could be recognized other than those included in some of the previously-explored databases, and simultaneously meeting the criteria set for a so-called agritourism working farm (a farm where agricultural activities are practised, though not necessarily full-time, providing on-farm services like lodging and accommodations, food and beverages, and leisure activities, according to Phillips et al., 2010). More than one hundred subjects were thus excluded as they specialized exclusively in horse riding; Internet databases normally comprise more than a thousand of such enterprises and the prominent position of horse riding within rural tourism can be inferred therefrom. Given the specificity of tourist ventures oriented this way, they were not included in this study. Due to the operation of such entities, only one third of farms diversified into tourism as captured by Agrocensus 2010 (CSO, 2011) were found to be suitable for the purposes of this study. In fact, the sum of farms quoted by Agrocensus 2010 comprised even those agricultural entrepreneurs for whom tourism represents only a marginal activity with minimum impact (therefore no promotion is needed and advertising costs are avoided), and the very farms specialized in horse breeding and horse riding, i.e. nonworking farms (Phillip et al., 2010, as well as Lukić, 2013 in the study on farm tourism in Croatia) were included.

After removing those farm entities not meeting the working farm criteria, 209 farms actively supplying agritourism as a product were included in a final database (with only 6 per cent of these not providing accommodations). Since organic agriculture "provides a significant opportunity for a working farm, owing to the labour-intensive nature of the production techniques employed" (Phillip et al., 2010, p. 757), it is not surprising that one third of the farms included in this study as agritourism working farms qualify as organic farms as well.

Having established the final study sample, the farms were subsequently localized at the muncipality level, which enabled an analysis of selected characteristics of agritourist space in the Czech Republic. Eventually, the location determined for each farm had to be related to the following municipality indicators (as of 31/12/ 2011: CSO, 2012):

- countryside/city (based on the status of the municipality or population size and population density);

- development features of municipalities (based on the typology of municipalities established by the Ministry of Regional Development of the Czech Republic (2013), identifying peripheral, stabilized and developing urbanized areas, taking into account selected features of socio-economic status, spatial potential, and the dynamics of development);

- the size of the area potentially utilized for recreation/ recreational area potential (according to Vystoupil et al., 2007); 
- presence and proportion of the protected landscape areas (PLAs) or national parks;

- the ecological stability of the landscape (according to the coefficient of ecological stability calculated as a share of ecologically important areas (hop fields, vineyards, gardens, orchards, grasslands, forest land and water areas) to areas of low environmental stability (arable land, built-up areas and other areas) by CSO (2012);

- presence of Less Favoured Areas (LFAs) for agriculture (definition of mountain [according to altitude and slope], other and specific indicators (according to land productivity, population density and the share of workers in agriculture] according to the Ministry of Agriculture of the Czech Republic, 2011); and

- current touristic utilization of the locality (on the basis of the number of accommodation facilities).

Farm location was also related to the territorial administrative units of municipalities with extended powers, with selected indicators (see below) reaching the levels from 1-5 (5 indicating very large potential or very high level of an activity). Specifically, based on the calculations of the Institute for Spatial Development (2010), characteristics or indicators employed were as follows:

- the overall potential for the tourism industry (on the basis of aggregate scoring of selected area and point features which are considered attractive in terms of tourism); and

- current utilization of the locality for tourism (based on the degree of utilization of accommodations and lodging).

\section{Czech agritourist space}

The spectrum of factors affecting this branch of tourism in some way or another is very broad: in individual countries, agritourist space is shaped to varying extent by natural conditions and elements of a socio-cultural nature (Sznajder et al., 2009; Dubois, Schmitz, 2013). While, for instance, in the Netherlands, agritourism is generally associated with a certain tradition of leisure time spending and active participation of visitors in some forms of activities organized by farms specialized on tourists (Canoves et al., 2009), in Austria, it is strongly attached to the natural attractiveness occasioned by the alpine character, therefore allowing a different (in contrast to the Netherlands) holiday experience (downhill or cross-country skiing, hiking) (Nilsson, 2002; Forbord et al., 2012). With respect to the diversity of landscape and rural space in the Czech Republic, questions should be raised about the nature of agritourist space in this country.

Notwithstanding the fact that two-thirds of the monitored farm holdings are located in rural municipalities (according to municipality status), one-quarter of them operate in cities, with some of them running their business even in the regional cities (Hradec Králové, Jihlava, Karlovy Vary and Zlín). This corresponds to the fact that more than one quarter of farms operate in the developing urbanized area of the Czech Republic, consisting of metropolitan and agglomeration areas and regional centres (Ministry of Regional Development, 2013). Lukić (2013) documented in a case study from Croatia that the greatest number of settlements with households with agricultural production tourism, accommodation and other leisure activities - are located in economically diversified, mainly tourist rural and urbanized settlements. Actually, it is these urbanized areas with high concentrations of people living in flats and lacking any contact with nature and livestock, which represent the main centres of interest in rural tourism or agritourism (Sznajder et al., 2009). Dubois and Schmitz (2013, p. 299) even identify a "suburban agritourism" that is developed in Wallonia (Belgium) and state that "at the edge of urban agglomerations (less than $15 \mathrm{~km}$ ), agritourist accommodations in Wallonia can be found everywhere". Using the two-thousand inhabitants' limit and a population density of less than 150 inhabitants per $\mathrm{km}^{2}$, it was found that somewhat less than 70 per cent of the monitored farms fell within this category. Nearly one-quarter of farms then operates in the peripheral rural areas, characterized as a territory with accumulated negative features such as the lack of facilities, poor accessibility and high unemployment (Ministry of Regional Development, 2013).

It can, however, be argued that a particular municipality in itself is not decisive with respect to the location of agritourism farms, since it is outweighed by the actual accessibility of any farm and its produce (Getz and Carlsen, 2005). From this perspective, only one third of farms was situated within the $20 \mathrm{~km}$ distance from the largest Czech cities (municipalities of more than 50,000 inhabitants). Nevertheless, the evergrowing mobility of the Czech population has a significant impact on the availability of agritourist enterprises. The degree of employability and popularity of agritourism in the hinterland of the largest Czech cities is nonetheless reduced due to the characteristic concentration of second-homes and cottages in the area (Kubeš, 2011; Vágner et al., 2011).

Yet another question arises as to whether farms aimed at providing tourist services operate in areas of considerable tourist attractiveness and great potential for the development of the tourism industry. On the other hand, do they rather tend to supply their agritourist products in regions with little or no natural potential for tourism, and factors such as vicinity to the source of demand, uniqueness of their on-farm additional programmes or cultural-historical prerequisites for the development of tourism in the area, are perceived as more critical by these operators. Cigale et al. (2013, p. 344) show that the "occurrence of tourist farms is primarily the result of farmers' needs and opportunities, and only on the second place of expressed demand of tourism market" in Slovenia. Nearly two-thirds of municipalities where the monitored farms are located exceed the value of recreational area potential of the Czech Republic (51\%), with one fifth of them even reaching the status of areas with high potential (over 75\%) (namely the mountain areas; see Fig. 2). A mere $5 \%$ of farms are based in municipalities of low recreational area potential (i.e. below $20 \%$ ), defined by Vystoupil et al. (2006) as an intensively exploited agricultural landscape with very little suitable natural conditions for tourism and recreation.

This may also be demonstrated by the fact that only onequarter of farms is concentrated in municipalities located outside the Less Favoured Areas for agriculture. Agritourism is indeed developed particularly in areas lacking suitable conditions for agricultural activities (as for organic farming, as much as $85 \%$ of the identified subjects are located within LFAs), where farms are forced to expand their revenue opportunities outside the sector of agriculture, which is considered one of the important elements of multifunctional agriculture (Marsden, Sonnino, 2008) or multifunctionality in agriculture (Wilson, 2008). Nearly one-third of farms are located in mountainous LFAs, despite the fact that merely $13 \%$ of municipalities and $15 \%$ of agricultural land fall into this category in the Czech Republic (Štolbová, Hlavsa, 2010). 
Therefore, farms focused on agritourism are predominantly located in piedmont and highland landscapes with favourable natural conditions for tourism or in the above-mentioned mountain landscapes with very favourable conditions - more than half the farms in the Czech Republic are situated in the first or the latter zone while simultaneously less than one-quarter of municipalities fall within these localities (Vystoupil et al., 2006). To perceive the location on a larger scale, more than four-fifths of farms are located within $10 \mathrm{~km}$ distance to areas with a very significant potential (distance of the farm to the boundary of such an area).

With regard to these characteristics of farm location, the research sample of corresponding farms comprises only a minimum of subjects that offer tourist services in areas of above-average utilization, with a clear disruption of natural structures (i.e. municipalities with a coefficient of ecological stability less than 0.3: Míchal, 1994). In contrast, the majority of farms operate in areas where technical objects occur in relative harmony with the preserved landscape (coefficient of ecological stability $>1$ ). In the case of organic farms, this factor is even more essential: $79 \%$ of all identified organic farms were located in areas with a coefficient greater than one (Fig. 3).

As a key factor for the location of farms, the attractiveness of nature and landscape is further underlined by the fact that one-third of farms was directly located in a protected landscape area or in a national park (constituting $16 \%$ of the Czech Republic's area). Exceptions were only the PLAs of

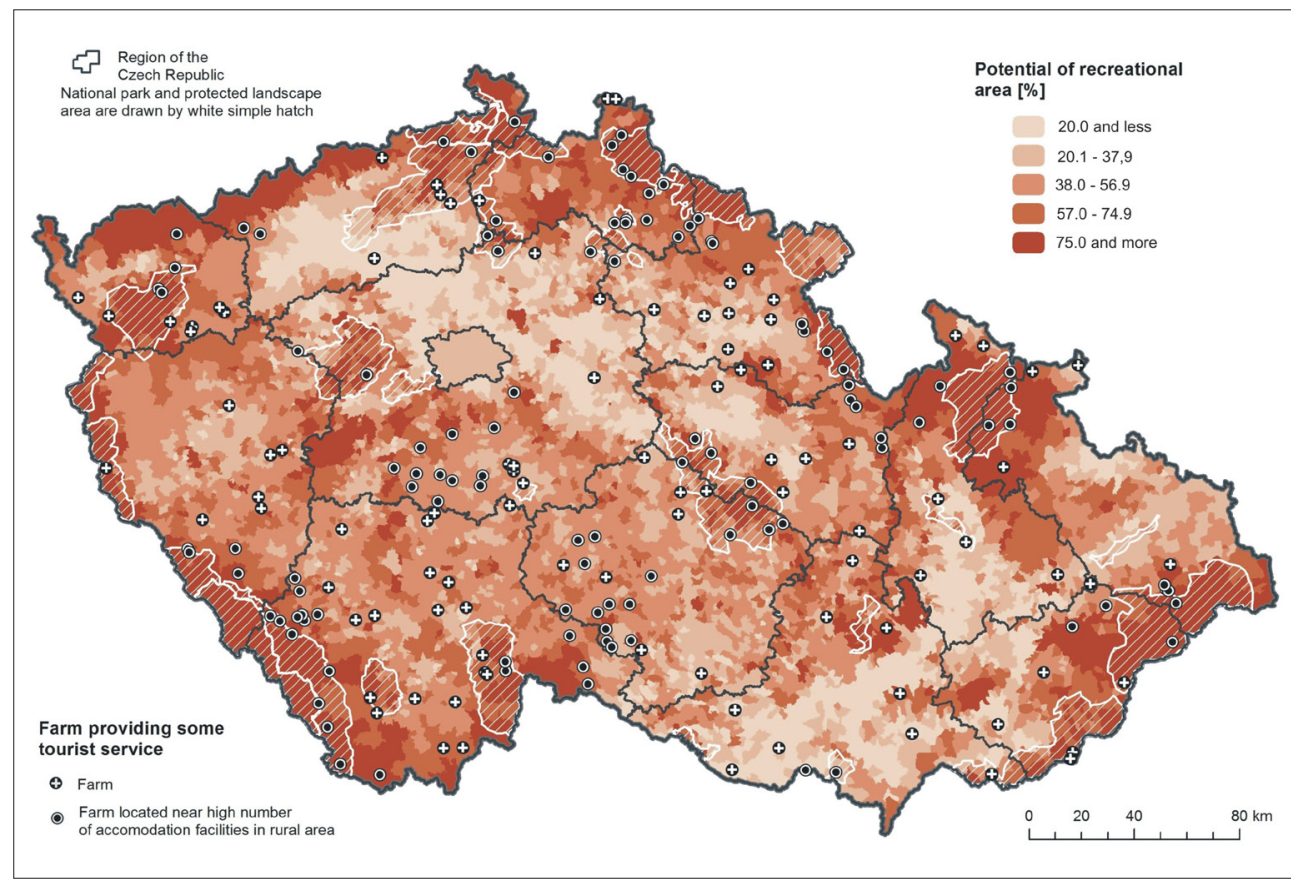

Fig. 2: Agritourism according to the recreational area potential in the Czech Republic in 2012 Source: Author; Potential of recreational area based on CSO (2012)

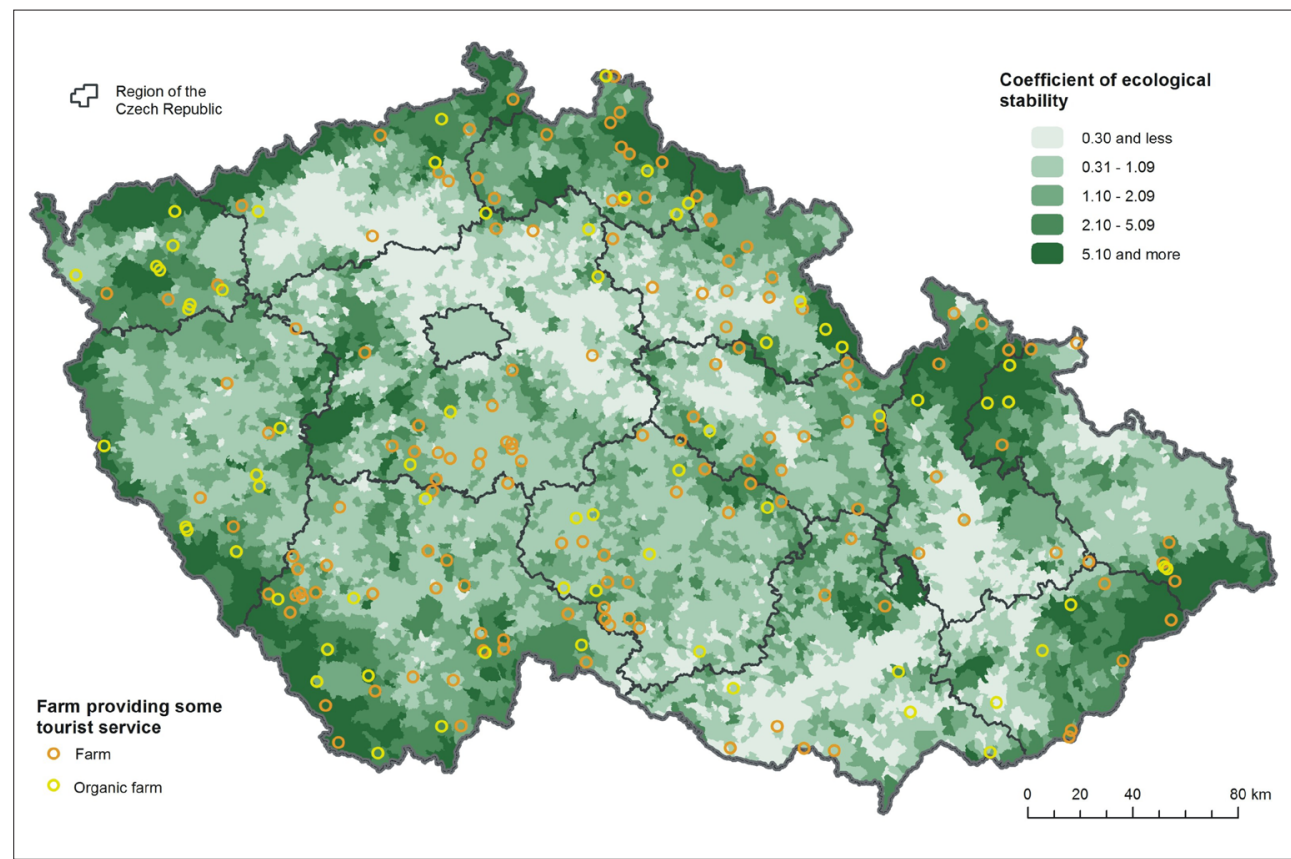

Fig. 3: Agritourism on organic farms with respect to landscape ecological stability in the Czech Republic in 2012 Source: Author; Coefficient of ecological stability based on CSO (2012) 
Broumovsko, Český Kras, Moravský Kras and Poodří, and the České Švýcarsko and Podyjí national parks, where none of the monitored farms operates. Nevertheless, more than three-quarters of farms are located within $20 \mathrm{~km}$ distance from one of the PLAs or national parks, or to its borders (Fig 4 - see cover p. 2).

The intertwining of agritourism with the areas of moderate to high tourism potential is manifested in the fact that more than four of five of the analyzed farms are located in municipalities with extended powers of such nature, in spite of the fact that, according to ISD (2010), half of all the municipalities with extended powers in the Czech Republic have only limited to very limited tourism potential (Fig. 5).

In order to characterize the Czech agritourist space, it is subsequently vital to explore whether Czech agritourism farms tend to localize in "traditional" and already-frequented tourist areas, thereby complementing the existing range of services available in a given locality, or whether they are more likely to operate in areas not so burdened with tourism. Almost twothirds of the farms have launched agritourism businesses in municipalities where at least one competitor already operated (usually a collective accommodation facility); in one quarter of the cases, these farms operated in an intensively-used area with respect to tourism (more than six collective accommodation facilities at the site). As the map (Fig. 2) reveals, taking into account the hinterlands of farms (municipalities within $10 \mathrm{~km}$ distance), as many as 9 of 10 of the studied farms were located in the vicinity of a higher concentration of accommodation facilities in a municipality (more than six collective accommodation facilities). Even in the case that only the rural areas are accounted for, it is still evident that farms are located within the reach of areas with a considerable supply of tourist services (more than one half of the surveyed farms).

In accord with the conclusions of this paper and the results of Vystoupil et al. (2006), the identified areas where agritourism is concentrated, rank among regions functioning as significant or very significant tourist and recreational localities (regarding the number of beds in collective accommodation facilities per thousand inhabitants), whose landscapes are exposed to a comparatively higher touristrecreational burden (number of beds per $\mathrm{km}^{2}$ ) - namely the Jeseníky Mts. and the Železné Mts. (Vystoupil et al., 2007, p. 50). Despite this, however, it is obvious with regard to the number of farms offering services in tourism in these regions (mostly the stabilized and peripheral rural areas), that their impact is only marginal, as various studies have confirmed (for the region of Jesenicko, see e.g. Havrlant, 2010).

\section{Conclusions}

With respect to the low number of the identified farms diversifying their activities into tourism, it is first appropriate to highlight the two following general findings. First, it might be considered that in the Czech Republic this form of tourism has not yet won recognition, although in some of the "new Member States" (i.e. countries outside the EU-15) or the "post-totalitarian states" (e.g. Poland, Slovenia), this form of tourism has been developed successfully (Verbole, 2000; Durydiwka, 2003; Svobodová, 2008; PotočnikSlavič, Schmitz, 2013). Therefore, agritourism in the Czech context still does not count as a business venture that would contribute fundamentally to the revitalization of rural space, and therefore it may still be labelled as an overestimated form of leisure, in accord with Perlín (1999).

Second, despite the fact that it could be presumed on the basis of the application of statistical measures (e.g. the Gini coefficient) that agritourism in the Czech Republic is distributed unequally (the value of Gini coefficient increases correspondingly with the decreasing territorial unit and reaches its highest value at the municipality level where it approximates to 1), the small number of the identified farms diversified into tourism renders any such interpretation difficult. While more than a half of the monitored farms were concentrated in $29 \%$ of regions (NUTS 3), in the case of districts (NUTS 4 ) it was only $21 \%$ of the units and in the case of municipalities with extended powers more than half of the farms are concentrated in only $15 \%$ of these units (in nearly a half of them, no agritourism farm was located).

The present article has not only revealed the low significance of agritourism as a whole, but it has also uncovered to some extent the following facts related to agritourist space in the Czech Republic:

- The peripheral rural areas, which are characterized by non-development features, such as remoteness, lack of facilities and a high level of unemployment, are less attractive for farms operating in the field of tourism than the developing urbanized area with the greatest development potential and dynamics in the Czech Republic (a finding similar to Lukic (2013) in the study of farm tourism in Croatia);

- Despite the generally observed weakening of the interrelationship of the countryside and the agriculture (Murdoch et al., 2003; Woods, 2005), the link between agritourism and the rural space/municipalities in the Czech Republic is still very important. On the other hand,

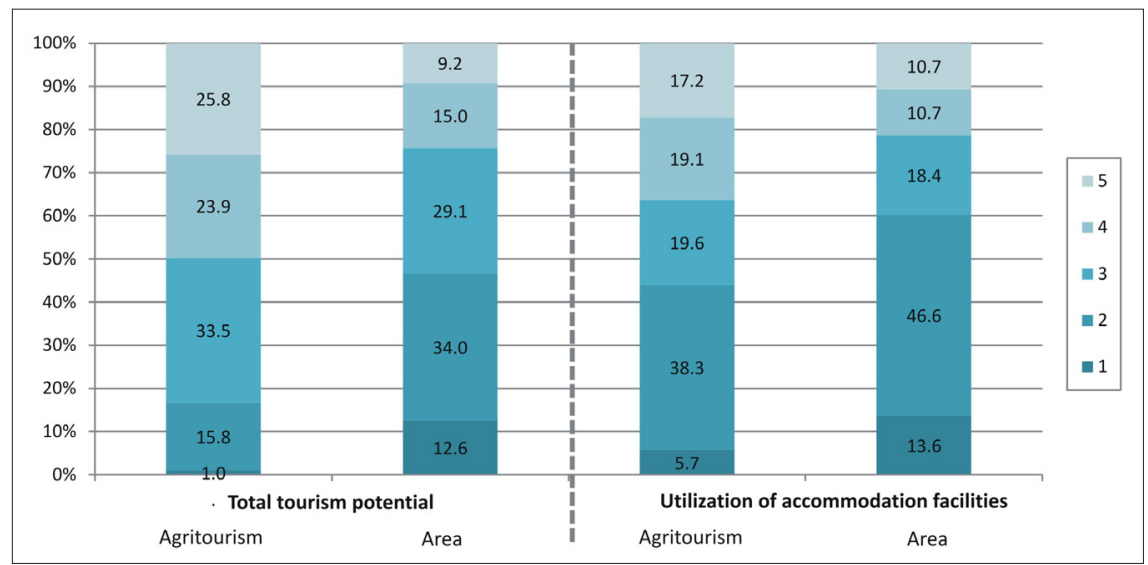

Fig. 5: Comparison of the proportion of agritourism and areas of municipalities with extended powers in the Czech Republic according to the level of coefficients of total tourism potential and utilization of accommodation facilities (5 indicating very large potential or very high level of an utilization). Source: Author; based on ISD, 2010 
it is the proximity to the cities that confers an advantage on farms as being easily accessible to the key subjects of demand for agritourism products (Sznajder et al., 2009; Lukić, 2013), and an increasing trend of the location of farms in the urbanized areas of the Czech Republic and in their vicinity may be anticipated;

- The location of more than three quarters of farms in less favoured areas for agriculture should be explained not only via the likely positive potential of any particular territory for tourism development (see below), but also with regard to the necessity to expand farm income opportunities outside of agricultural activities;

- As regards agritourist space (and similarly, rural tourism and tourism in general; Bína, 2002; Ryglová, 2007), the natural landscape component is apparently the predominant one because agritourism in the Czech Republic is interconnected with valuable natural environments (Fig. 6 - see cover p. 4). The majority of farms included in the survey operate in one of the two categories of the most attractive tourism areas, i.e. either in mountain landscapes with very favourable conditions, or in piedmont and highland landscapes with favourable natural conditions for tourism development (according to the regionalization applied by Vystoupil et al., 2006). It is the opportunities for diversification into tourism available to local farms that co-determines the strong multifunctionality of these areas (Wilson, 2008); and

- Protected landscape areas and national parks, which are traditionally perceived as important elements of the tourism potential in any area (Vystoupil et al., 2007; Sznajder et al., 2009; Havrlant, 2010; Lukić, 2013), similarly play a significant role in agritourism of the Czech Republic (more than 50\% were located in the vicinity of PLAs).

It is, therefore, not surprising that ecotourism principles aimed at minimizing the impacts of tourism on the natural environment and increasing the interconnection with the locality and the local community (Roberts, Hall, 2001), are gradually being enhanced, which in turn places even greater demands on the farms involved in tourism with respect to their organization and management. This is even amplified where agritourism farms operate in a preserved nature and in a landscape of high value and ecological stability - almost two thirds of the sample farms functioned in such an environment in the Czech Republic (Fig. 7 - see cover p. 4). As for organic farms offering services in tourism, even more than threequarters of them are concentrated in these valuable areas. As pointed out by Choo and Jamal (2009), however, the presence of organic farms does not necessarily stand for the promotion and fulfilment of the principles of ecotourism.

International studies reveal the tendency of agritourism to concentrate in areas already intensively utilized by tourists and established for tourism purposes (Durydiwka, 2003; Fleischer and Thetchik, 2005; Sharpley and Vass, 2006; Lukić, 2013), as greater profit generation is anticipated in such localities by agritourism farms. This research has indicated that even in the Czech Republic, agritourism farms are more likely to operate in popular tourist areas (whether in terms of the touristrecreational function or the tourist burden on landscape: see Vystoupil et al., 2007, p. 50). This is because almost two-thirds of the farms complemented another collective accommodation facility at the place of their operation and were situated in the immediate hinterland (within $10 \mathrm{~km}$ ) of municipalities with a high supply of necessary accommodations. In such locations, agritourism supplements and enriches local tourism services, but it also contributes to an even greater pressure exerted on local natural or cultural attractions. Research on sustainable agritourism in these types of localities would certainly enrich not only the study of tourism geography and rural geography, but it would also include research approaches to the issues of sustainability, thus connecting them to the framework of sustainable tourism.

\section{Acknowledgement}

This research project: "The Czech economy within the integration and globalization processes and the development of agriculture and service sectors in the conditions of the integrated European market", was supported by the Ministry of Education, Youth and Sports of the Czech Republic (project No. MSM6215648904).

\section{References:}

BARBIERI, C., MAHONEY, E. (2009): Why is diversification an attractive farm adjustment strategy? Insights from Texas farmers and ranchers. Journal of Rural Studies, Vol. 25, No. 1, p. 58-66.

BIČÍK I., JANČÁK V. (2005): Transformační procesy v českém zemědělství po roce 1990. Praha, Přrírodovědecká fakulta Univerzity Karlovy KSGRR. 104 pp.

BIČÍK, I., KABRDA, J. (2007): Land use changes in Czech border regions (1845-2000). AUC Geographica, Vol. 42, No. 1-2, p. 23-52.

BÍNA, J. (2002): Hodnocení potenciálu cestovního ruchu v obcích České republiky. Urbanismus a územní rozvoj, Vol. 5, p. 2-11.

BUDAY, Š., FEDERIČOVÁ, Z., VAJCÍKOVÁ, R. (2009): Diversification of farm business. Agricultural Economics, Vol. 55, No. 2, p. 77-83.

CANOVES, G., VILLARINO, M., PRIETSLEY, G., BLANCO, A. (2004): Rural tourism in Spain: an analysis of recent evolution. Geoforum, Vol. 35, No. 6, p. 755-769.

CHOO, H., JAMAL, T. (2009): Tourism on organic farms in South Korea: a new form of ecotourism? Journal of Sustainable Tourism, Vol. 17, No. 4, p. 431-454.

CIGALE, D., LAMPIČ, B., POTOČNIK-SLAVIČ, I. (2013): Interrelations between tourism offer and tourism demand in the case of farm tourism in Slovenia. European Countryside, Vol. 5, No. 4, p. 339-355.

CLARKE, J., DENMAN, R., HICKMAN, G., SLOVÁK, J. (2001): Rural tourism in Roznava Okres: a Slovak case study. Tourism Management, Vol. 22, No. 2, p. 193-202.

CHROMÝ, P., JANČÁK, V., MARADA, M., HAVLÍČEK, T. (2011): Venkov - žitý prostor: regionální diferenciace percepce venkova představiteli venkovských obcí v Česku. Geografie, Vol. 116, No. 1, p. 23-45.

CSO (2011): Agrocensus, regions - Farm Structure Survey and Survey on Agricultural Production Methods 2010. [online]. Accessible at: URL: http://www.czso.cz/ csu/2011edicniplan.nsf/p/2129-11

CSO (2012): ČSÚ a územně analytické podklady. [online]. Accessile at: URL: http://www.czso.cz/csu/redakce.nsf/i/ csu_a_uzemne_analyticke_podklady

DÖMEOVA, L., JINDROVA, A. (2011): Rural tourism and its contribution to the development of countryside. Acta Universitatis Agriculturea et Silviculturae Mendelianae Brunensis, Vol. 59, No. 2, p. 59-64. 
DUBOIS, C., SCHMITZ, S. (2013): What is the position of agritourism on the walloon tourist market? European Countryside, Vol. 5, No. 4, p. 295-307.

DURYDIWKA, M. (2003): Tourism as a factor of the activation the rural areas in Poland. AUC Geographica, Vol. 38, No. 1, p. 53-58.

FLEISCHER, A., TCHETCHIK, A. (2005): Does rural tourism benefit from agriculture? Tourism Management, Vol. 26, p. 493-501.

FORBORD, M., SCHERMER, M., GRIEßMAIR, K. (2012): Stability and variety - Products, organization and institutionalization in farm tourism. Tourism Management, Vol. 33, No. 4, p. 895-909.

GETZ, D., CARLSEN, J. (2005): Family business in tourism. Annals of Tourism Research, Vol. 32, No. 1, p. 237-258.

HAUGEN, M. S., VIK, J. (2008): Farmers as entrepreneurs: the case of farm-based tourism. International Journal of Entrepreneurship and Small Business, Vol. 6, No. 3, p. 321-336.

HAVRLANT, J. (2010): The recreational potential of the Jeseníky region (Czech Republic) and the influence of soft factors on its developments. Moravian Geographical reports, Vol. 18, No. 1, p. 23-37.

ILBERY, B. W., BOWLER, I. R. (1998): From agricultural productivism to post-productivism. In: Ilbery, B. [ed.]: The geography of rural change. Essex, Addison Wesley Longmann Limited, p. 57-84.

Institute for Spatial Development (2010): Využití potenciálu cestovního ruchu v České republice (Závěrečná zpráva úkolu B.9/CR). Brno, ISD. 67 pp.

JANČÁK, V. (2001): Př́íspěvek ke geografickému výzkumu periferních oblastí na mikroregionální úrovni. Geografie, Vol. 106, No. 1. p. 26-35.

JARÁBKOVÁ, J. (2010): The rural areas - the unutilized potential in light of tourism. Agricultural Economics Czech, Vol. 56, No. 11, p. 532-539.

JONGENEEL, R., POLMAN, N. B. P., SLANGEN, L. H. G. (2008): Why are Dutch farmers going multifunctional? Land Use Policy, Vol. 25, No. 1, p. 81-94.

KLAPKA, P., KLAPKOVÁ, E., MARTINÁT, S. (2005): Ekologické formy zemědělství v Krkonoších: krajina, ekoturismus, udržitelnost. Opera Corcontica, Vol. 42, p. 127-137.

KUBEŠ, J. (2011): Cabin landscape areas in the Czech Republic. Geografický Časopis, Vol. 63, No. 1, p. 53-68.

LUKIĆ, A. (2013): Tourism, farm diversification and plurality of rurality: case study of Croatia. European Countryside, Vol. 5, No. 4, p. 356-376.

MARSDEN, T., SONNINO, R. (2008): Rural development and the regional state: Denying multifunctional agriculture in the UK. Journal of Rural Studies, Vol. 24, p. 422-431.

MíCHAL, I. (1994): Ekologická stabilita. Brno, Veronica, 275 pp.

MIKULEC, J., ANTOUŠKOVÁ, M. (2011): Landscape and tourism potential in the protected landscape areas. Agricultural Economics - Czech, Vol. 57, No. 6, p. 272-278.

Ministry of Agriculture of the Czech Republic (2011): Methodology for the implementation of Government Regulation No. 75/2007 Coll. Prague, MoA. 16 pp.
Ministry of Regional Development of the Czech Republic (2007): Rural development programme of the Czech Republic 2007-2013. Prague, Ministry of Regional Development, 327 pp.

MURDOCH, J., LOWE, P., WARD, N., MARSDEN, T. (2003): The differentiated countryside. Londýn, Routledge, $181 \mathrm{pp}$.

NILSSON, P. A. (2002): Staying on farms: An ideological background. Annals of Tourism Research, Vol. 29, No. 1, p. 7-24.

PERLÍN, R. (1999): Venkov, typologie venkovského prostoru. In: Malý, F., Viktoriová, B. [eds.]: Česká etnoekologie. Praha, Cargo Publishers, p. 87-106.

PHILLIP, S., HUNTER, C., BLACKSTOCK, K. (2010): A typology for defining agritourism. Tourism Management, Vol. 31, No. 6, p. 754-758.

POTOČNIK-SLAVIČ, I., SCHMITZ, S. (2013): Farm tourism across Europe. European Countryside, Vol. 5, No. 4, p. $265-274$.

RIBEIRO, M., MARQUES, C. (2002): Rural tourism and the development of less favoured areas - between rhetoric and practise. International Journal of Tourism Research, Vol. 4, No. 3, p. 211-220.

ROBERTS, L., HALL, D. (2001): Rural tourism and recreation: principles to practice. Oxon, CABI, $231 \mathrm{pp}$.

RYGLOVÁ, K. (2007): Limiting factors in the field of business activities in rural tourism. Agricultural Economics Czech, Vol. 52, No. 9, p. 421-431.

SHARPLEY, R., SHARPLEY, J. (1997): Rural tourism: An introduction. London, Thomson Business Press, $165 \mathrm{pp}$.

SHARPLEY, R., VASS, A. (2006): Tourism, farming and diversification: an attitudinal study. Tourism Management, Vol. 27, No. 5, p. 1040-1052.

SPIŠIAK, P. (2003): Agricultural production in Bratislava's sub-urban space (Pridunajsko Microregion). AUC Geographica, Vol. 38, No. 1. p. 403-414.

STŘELEČEK, F., LOSOSOVÁ, J., ZDENĚK, R. (2008): Economic results of agricultural holdings in less favoured areas. Agricultural Economics, Vol. 54, No. 11, p. 510-520.

SVOBODOVÁ, H. (2008): Comparison of selected CAP measures in the Czech Republic and Republic of Slovenia. Dela, Vol. 30, p. 123-138.

SVOBODOVÁ, H., KONEČNÝ, O., BINEK, J., GALVASOVÁ, I., CHABIČOVSKÁ, K., HOLEČEK, J., VĚŽNÍK, A., HYNEK, A. (2011): Synergie ve venkovském prostoru. Brno, GaREP, 114 pp.

SZNAJDER, M., PRZEZBÓRSKA, L., SCRIMGEOUR, F. (2009): Agritourism. Wallingford, CABI, $301 \mathrm{pp}$.

ŠIMKOVÁ, E. (2007): Strategic approaches to rural tourism and sustainable development of rural areas. Agricultural Economics - Czech, Vol. 53, No. 6, p. 263-270.

ŠKODOVÁ PARMOVÁ, D., DVOŘAK, V. (2009): Support of agroturism in the Czech Republic illustrated on the case of South Bohemian Region. Central European Journal of Regional Development and Tourism, Vol. 1, p. 156-164.

ŠTOLBOVÁ, M., HLAVSA, T. (2010): The impact of the LFAs payments on the FADN farms in the Czech Republic. Agricultural Economics, Vol. 54, No. 10, p. 489-497. 
TEW, C., BARBIERI, C. (2012): The perceived benefits of agritourism: The provider's perspective. Tourism Management, Vol. 33, No. 1, p. 215-224.

VÁGNER, J. (2007): Tourism development in the Visegrad Four countries in the period of the EU access. AUC Geographica, Vol. 42, No. 1-2, p. 75-89.

VÁGNER, J., MÜLLER, D. K., FIALOVÁ, D. (2011): Second home tourism in light of the historical-political and socio-geographical development of Czechia and Sweden. Geografie, Vol. 116, No. 2. p. 191-210.

VERBOLE, A. (2000): Actors, Discourses and Interfaces of Rural Tourism Development at the Local Community Level in Slovenia: Social and Political Dimensions of the Rural Tourism Development Process. Journal of Sustainable Tourism, Vol. 8, No. 6, p. 479-490.

VERNIMMEN,T.,BURGEOIS,M.,VANHUYLENBROECK, G., MEERT, H., VAN HECKE, E. (2003): Diversification as a survival strategy for marginal farms: exploratory research. In: Van Huylenbroeck, G., Durand, G. [eds.]: Multifunctional Agriculture: a New Paradigm for European Agriculture and Rural Development. Ashgate, Aldershot, p. 209- 224.
VĚŽNÍK, A., KONEČNÝ, O. (2011): Agriculture of the Czech Republic after Accession to the EU: Regional Differentiation. Moravian Geographical reports, Vol. 19, No. 1. p. 50-60.

VYSTOUPIL, J. et al. (2006): Atlas cestovního ruchu České republiky. Praha, MMR, $157 \mathrm{pp}$.

VYSTOUPIL, J. et al. (2007): Návrh nové rajonizace cestovního ruchu ČR. Brno, MU, 108 pp.

WILLIAMS, A. M., BALÁŽ, V. (2002): The Czech and Slovak Republics: conceptual issues in the economic analysis of tourism in transition. Tourism Management, Vol. 23, No. 1 , p. 37-45.

WILSON, G. A. (2008): From "weak" to "strong" multifunctionality: Conceptualising farm-level multifunctional transitional pathways. Journal of Rural Studies, Vol. 24, p. 367-383.

WILSON, G. A. (2009): The spatiality of multifunctional agriculture: A human geography perspective. Geoforum, Vol. 40, No. 2, p. 269-280.

WOODS, M. (2005): Rural Geography. London, Sage, 330 pp.

ZUZÁK, R., HOŘEJŠÍ, P. (2004): Possibilities of agri-tourism in the Integro Micro-region. Agricultural Economics Czech, Vol. 50, No. 5, p. 227-230.

\section{Authors' address:}

Mgr. Ondřej KONEČNÝ,

Department of Regional Development and Public Administration, Mendel University

Tř. Generála Píky 7, 31300 Brno, Czech Republic

e-mail: ondrej.konecny@mendelu.cz

Initial submission 30 May 2013, final acceptance 16 February 2014

Please cite this article as:

KONEČNÝ, O. (2014): Geographical perspectives on agritourism in the Czech Republic. Moravian Geographical Reports, Vol. 22, No. 1, p. 15-23. DOI: 10.2478/mgr-2014-0002. 